SAND77-0968

Unlimited Release

\title{
MASTER
}

\section{Irrigation Data Base for Arizona}

Irving J. Hall, Sharla G. Vandevender

Preparêd by Sandia Laboratories, Albuquerque, New Mexico 87115 and Livermore, California 94550 for the United States Department of Energy under Contract AT(29-1)-789

January 1978

\section{Sandia Laboratories}




\section{DISCLAIMER}

This report was prepared as an account of work sponsored by an agency of the United States Government. Neither the United States Government nor any agency Thereof, nor any of their employees, makes any warranty, express or implied, or assumes any legal liability or responsibility for the accuracy, completeness, or usefulness of any information, apparatus, product, or process disclosed, or represents that its use would not infringe privately owned rights. Reference herein to any specific commercial product, process, or service by trade name, trademark, manufacturer, or otherwise does not necessarily constitute or imply its endorsement, recommendation, or favoring by the United States Government or any agency thereof. The views and opinions of authors expressed herein do not necessarily state or reflect those of the United States Government or any agency thereof. 


\section{DISCLAIMER}

Portions of this document may be illegible in electronic image products. Images are produced from the best available original document. 
Issued by Sandia Laboratories, operated for the United States Department of Energy by Sandia Corporation.

\section{NOTICE}

This report was prepared as an account of work sponsored by the United States Government. Neither the United States nor the United States Department of Energy, nor any of their employees, nor any of their contractors, subcontractors, or their employees, makes any warranty, express or implied, or assumes any legal liability or responsibility for the accuracy, completeness or usefulness of any information, apparatus, product or process disclosed, or represents that its use would not infringe privately owned rights.

Printed in the United States of America

Available from

National Technical Information Service

U. S. Department of Commerce

5285 Port Royal Road

Springfield, VA 22161

Price: Printed Copy $\$ 4.50$; Microfiche $\$ 3.00$ 
SAIN77-0968

Unlimited Release

\title{
Irrigation Data Base for Arizona
}

Irving J. Hall

Sharla G. Vandevender

\begin{abstract}
Part of Sandia Labs responsibility as technical manager of DOE's solar irrigation project is to determine the locations in the U.S. where solar energy might be used for irrigation. One of the first steps in determining these locations is to establish a data base for the agricultural states that extensively use irrigation. The data base must include information on the crops grown, the irrigation wells, and the irrigation pumps. This document contains the results of an effort to establish such a data base for the state of Arizona.
\end{abstract}


Introduction

This report contains data which describes irrigated agriculture in the State of Arizona. The date was compiled for use in the applicetion analy. sis of solar irrigetion systems. This effort hed two purposes: to establish a format for data compilation for the states of interest while assessing the difficulty of obteining the necessary data and to provide a data base for prelfminary applications onlysis and economic analysis for the solar irrigation program.

The time required to develop this preliminary data base makes it prohibitive to attempt to develop a similarly detalled data base for each area of concern. As a result, agricultural census data, although somewhat out-of-date; will be relied upon for the Western U. S. data still to be assernbled. Other data bases will also be used where possible to reduce the time reguired to ossemble data base which characterizes western agriculture.

\section{Methodology}

The ultimate objective of the solar irrigation program rate compilation is to provide suffirient information to delermine regions where solar irrigetion is most applicable. Arizona is the site of the $150 \mathrm{KWe}$ solar irrigation experiment. Therefore the state was chosen for the preliminary data compilation and application analysis.

Table 1 shows the type of data. which were required to meet the stated objective.

The data are grouped by groundwater well charasterietics, crup characteristics, pump energy use, surfare water pumping claracterlstics, and weter storage data. The data were compiled from the most current documents avoilable. ivumerous telephone discussions were held with authorities in the various fields to clarify the data. In some cases, datn are not available. The data were compiled for esch county in which irrigated agriculture is significant. These include Cochise (118,000 acres), Graham (56,000 acres), 
Maricopa (430,000 acres), Pima (50,000 acres), Pinal (210,700 acres), and Yuma (230,000 acres) based on 1970 data.

\section{Results}

Tabies 2 through 8 contain the data. Each data group in Table 1 is presented with explanatory notes. 
Table I

A. Wells

1. number (irrigation)

2. H'low rate (gpm)

3. lift (feet)

4. drawdown (feet)

5. annual pumpage (ac. ft.)

6. $\mathrm{H}_{2} \mathrm{O}$ temperature

7. operating hours total annual

8. distance between wells (feet)

9. water table depth

10. acres per well

B. Crops

1. number groundwater irrigated acres

2. number surface water irrigated acres

3. system (acres) flood gravity

4. system (acres) furrow flow

5. system (acres) sprinkler

6. Inches/acre water applien *

7. irrigated crop value per acre

8. irrigated crop yield per acre

C. Energy

1. energy coat ( $\$ / \mathrm{BIU})$

2. annual energy consumption (BTU)

3. 1980 aveilability of energy

D. Surface Water Pumped for Irrigation

1. number pumps

2. flow rate (gpm)

3. Iift (feet)

4. annual pumpage

5. operaiting hours total annual

6. total annual (acre feet)

7. distance between pumps

8. water temperature $\left({ }^{\circ} \mathrm{C}\right)$

E. Water Storage Data

1. seepage rate

2. cost of water storage

3. evaporation rate

* Item 6 is a matrix showing water demand for each $1 / 2$ month for each crop considered.

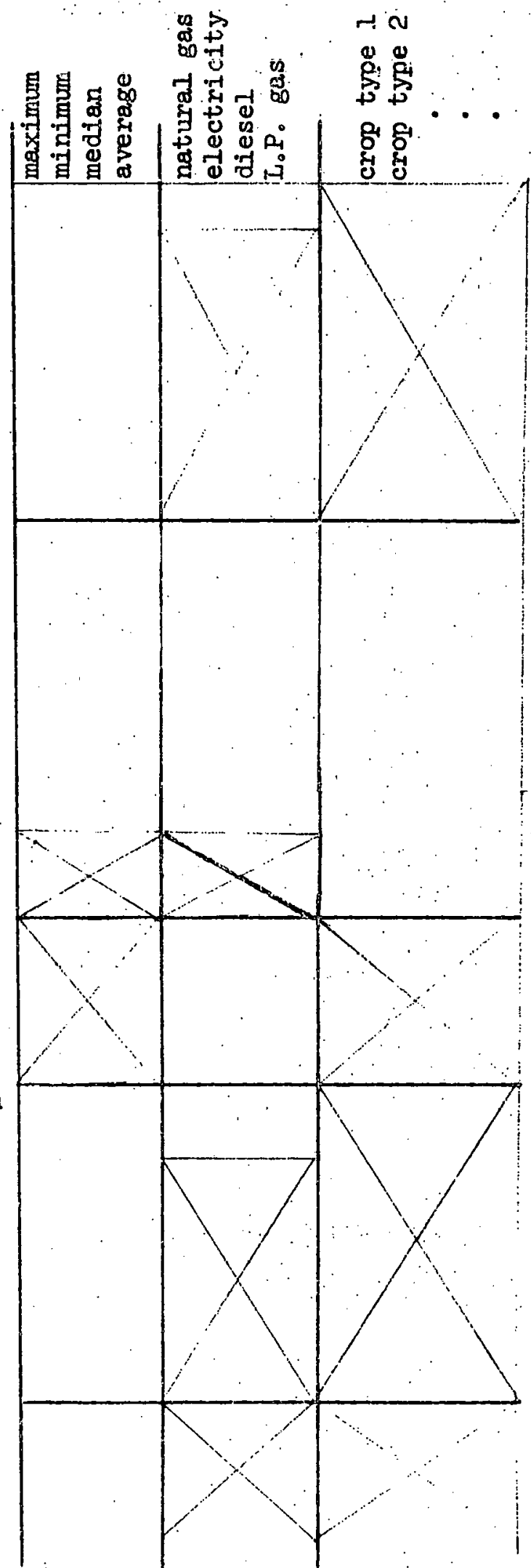


A. Wells

1. Number of irrigation wells. Data unavailable on a county basis for this parameter. There are about 7,000 irrigation wells in the state.

2. Flow rate (gpm). See Table 2.

3. Lift (feet) See Table.2.

4. Drawdown (feet) this parameter was not estimated.

5. Annual pumpage (acre-feet) See Table 2.

6. Water Temperature. See Table 2.

7. Total Annual operating hours. See Table 2.

8. Distance between wells.

We were not able to get good information on this parameter. However from conversations with several agriculture-type people in Arizona, we estimated that the minimum number of acres per well is about 120 and the maximum is about 200. A rule of thumb that irrigation specialists often use is $10 \mathrm{gal} / \mathrm{min} /$ acre. Hence a $1200 \mathrm{~g} / \mathrm{min}$ pump could irrigate about 120 acres. 
THIS PAGE

WAS INTENTIONALLY

LEFT BLANK 
C. Energy

1. Energy cost ( $\$ / B T U)$. We did not try to calculate values for this parameter. This data should be readily available from the power companies .

2. Annual Energy Consumption (BTU). See Table i. We do not have complete data for this parameter. The table gives numbers for 1976 electric consumption based on information from Jim Carter, Arizona Cotton Growers Association.

3. 1980 Availability of Energy - we do not have much information on this parameter. From conversations with several knowledgeable people we have concluded that very little natural gas will be available in 1980 . Most farmers are converting to electric power as quickly as possible.

D. Surface Water Pumped for Irrigation. We do not have specific information on surface water pumpage. Most of this type of pumping is done in Yuma county. According to Scot Hathorn, irrigation specialist at University of Arizona, the energy requirements for surface pumping are quite smali.

E. Other Data

1. Water Storage Efficiency (seepage rate). No data.

2. Cost of Water Storage. No data:

3. Evaporation Rate (inches/year). See Table 8. 


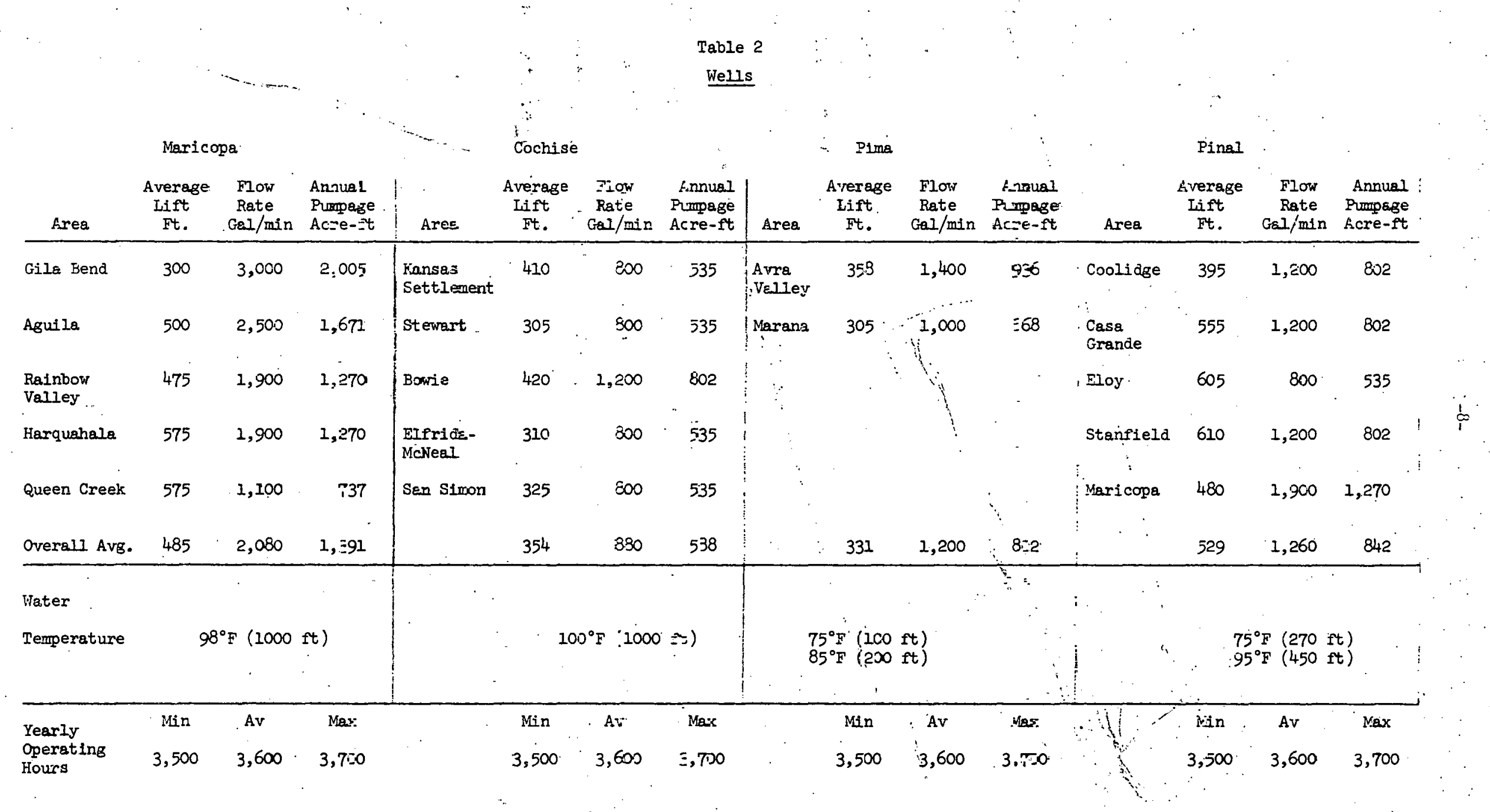


Table 2 (cont)

Notes:

1. No data avilable for Craham and Yuma counties - Pumpage for most of Yuma County and part of Graham County is for surface dralnage.

2. Lift, Flow, Pumpage, arid Total operating Hours data is from "Ar1zona Puñ Water Budgets 1976", References. [2], [3], [4], [5].

3. Water Temperature estimates are from [8]. 
Table 3

Ground and Surface Water Inrigation Information

\begin{tabular}{|c|c|c|c|c|c|c|c|}
\hline Irrigated Acreage, Acres & $\begin{array}{l}\text { Maric }=2 a * \\
430,200\end{array}$ & $\begin{array}{l}\text { Cochise } \\
128,000\end{array}$ & $\begin{array}{l}\text { Pima* } \\
50,000\end{array}$ & $\begin{array}{l}\text { Pinal* } \\
210.7 \mathrm{Co}\end{array}$ & $\begin{array}{l}\text { Graham } \\
56,000\end{array}$ & $\begin{array}{l}\text { Yuma* } \\
230,000\end{array}$ & \\
\hline $\begin{array}{l}\text { Surface water } \\
\text { Diversion, Acre-ft }\end{array}$ & 941,000 & 17,000 & $\vdots$ & 197:C00 & 113,000 & $1,878,000$ & $\because$ \\
\hline $\begin{array}{l}\text { o of Total } \\
\text { County Withdrawal }\end{array}$ & 31;: & $3.0 \%$ & $0 \%$ & $15 \%$ & $40 \%$ & $7 \varepsilon \%$ & . \\
\hline $\begin{array}{l}\% \text { of Total State } \\
\text { Surface Water Diversicn }\end{array}$ & $28.6 \%$ & $0.5 \%$ & $0 \%$ & 6.016 & $3.4 \%$ & $57.0 \%$ & \\
\hline $\begin{array}{l}\text { Ground Water } \\
\text { Pumpage, Acre-ft }\end{array}$ & $2,0449,0000$ & 505,000 & 412,000 & $1,115,00 \mathrm{CO}$ & 168,000 & $\begin{array}{l}180,000 \\
\frac{361,000}{541,000} \\
\end{array}$ & $\begin{array}{l}\text { (around } \\
\text { water) } \\
\text { (drainage } \\
\text { only) }\end{array}$ \\
\hline$\%$ of County Totel & $69 \%$ & $97 \%$ & $200 \%$ & $85 \%$ & $60 \%$ & $22 \%$ & 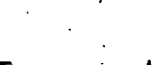 \\
\hline$\%$ of State Total & 41.30 & $10.2 \%$ & $8.3 \%$ & $22.4 \%$ & $3.4 \%$ & $\begin{array}{r}3.6 \% \\
11.6 \%\end{array}$ & $\therefore$ \\
\hline $\begin{array}{l}\text { Total Irrigation Weter, } \\
\text { Acre-ft. }\end{array}$ & $2,930,0000$ & 536,0100 & 412,000 & $1,312,0 \mathrm{OCC}$ & 281,000 & $2,419,000$ & $\therefore$ \\
\hline
\end{tabular}

1970. Conitions. Informetion is from "Inventory of Fesources and Lses." Ref [8].

* SJme souble croppling in these counties 
Table 4

System of Irrigation

Total Acres besed on "1975 Arizone Ag. Stat1stics" Ref. [6]

Percents based on 1969 USDA Census Data*

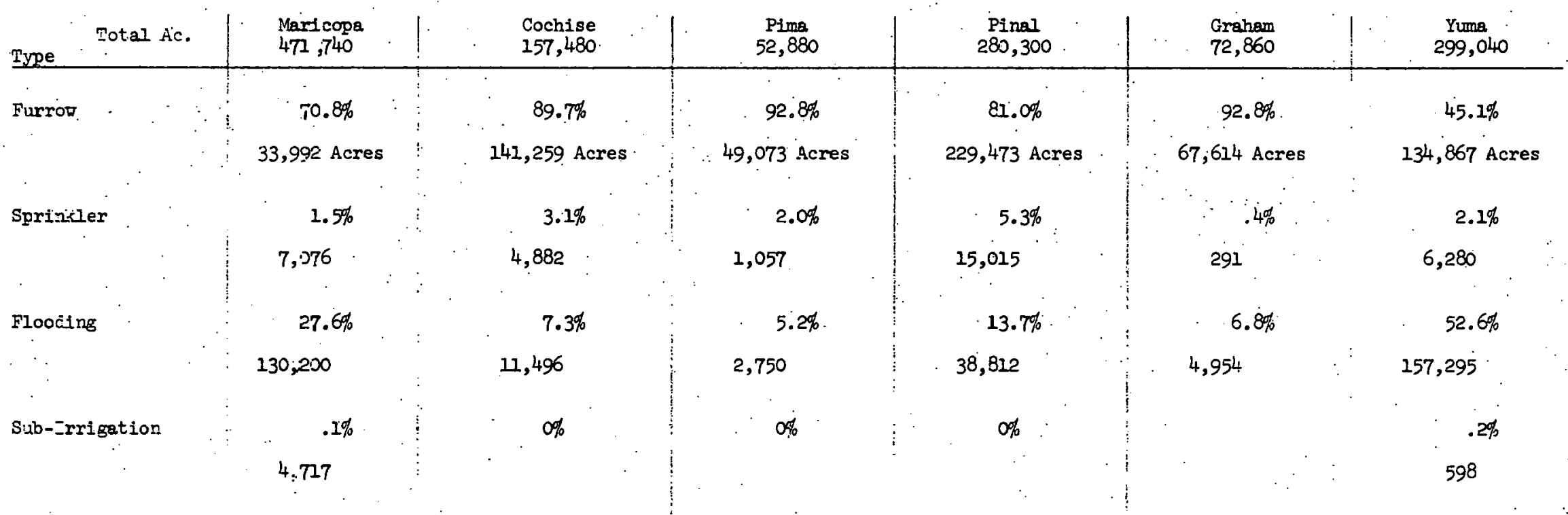

* Dverlap between systems of irrigation was neglected. For example, acreage that was both sprinkled and furrow irrigated wes counted twice. This overlap acreage is judged to be small. 
Table 5

Water Demend (Plant Consumptive Use)

Inches

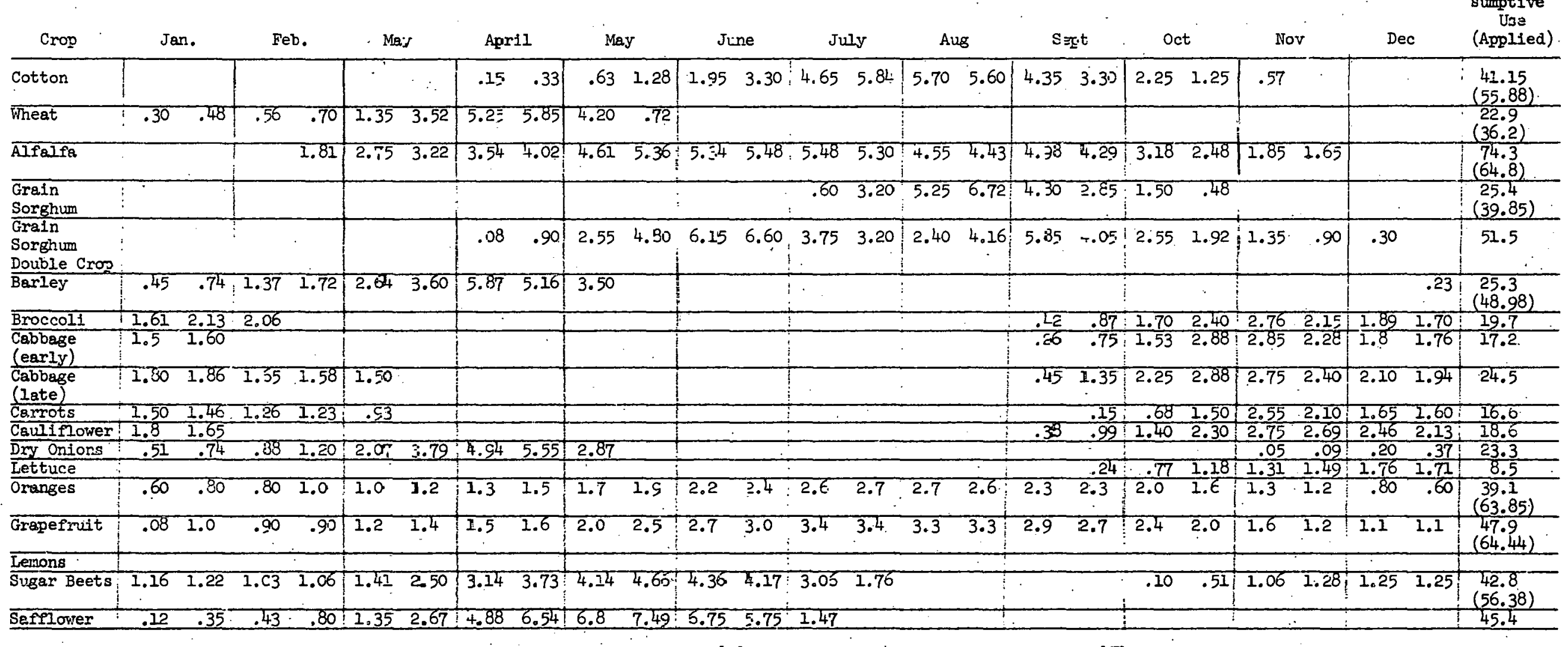

Consumotive use values are from "Consumptive Use by Crops in Arizona" Ref. [1]. Total Applied Values ere from Fef: [7]. 
Table 6

Crop Information by County (1975 Data from Ref [6])

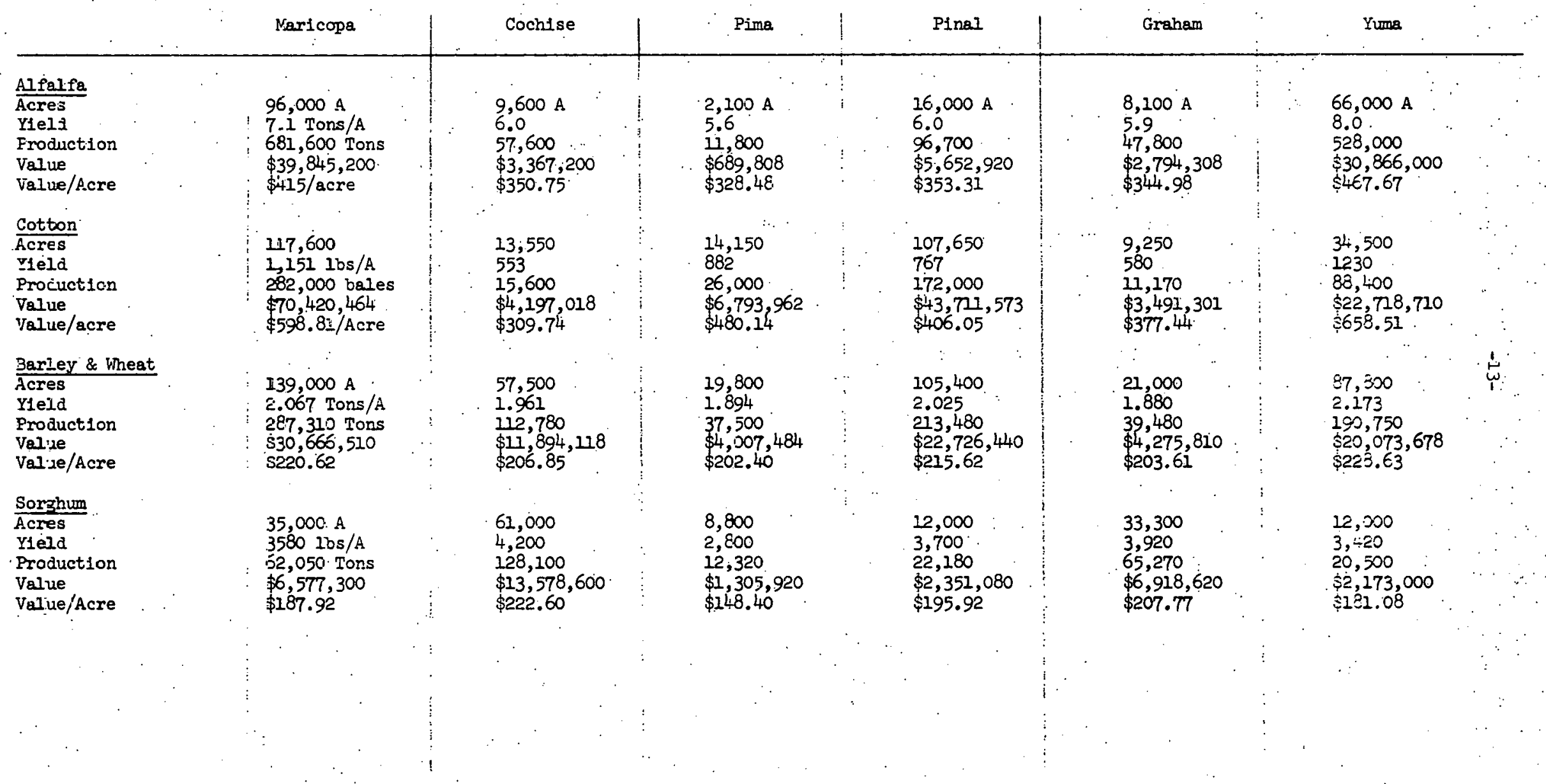


Table 6 (cont.)

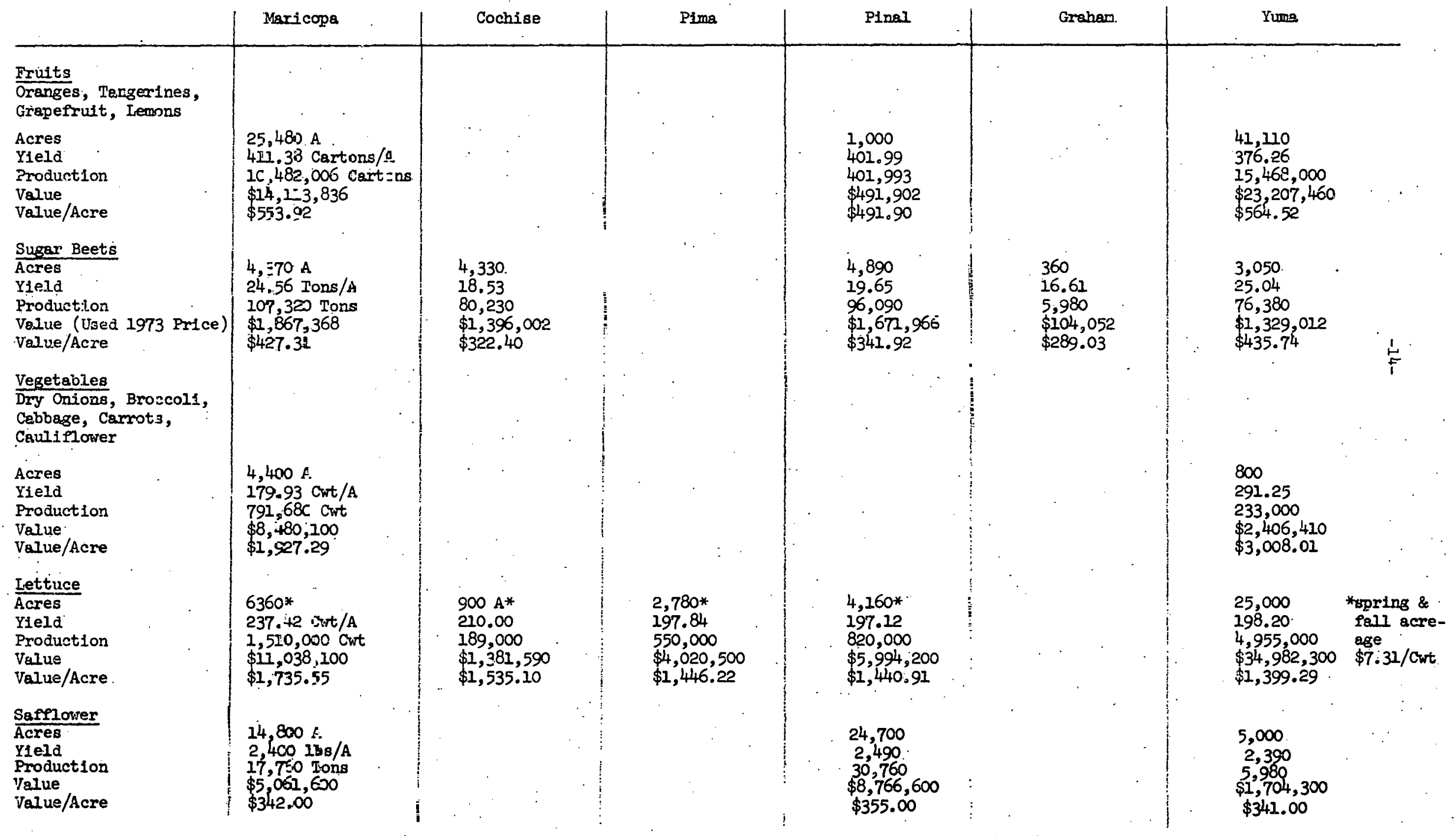


Table бa

Crop Information for Upland and Am. Pima Cotton

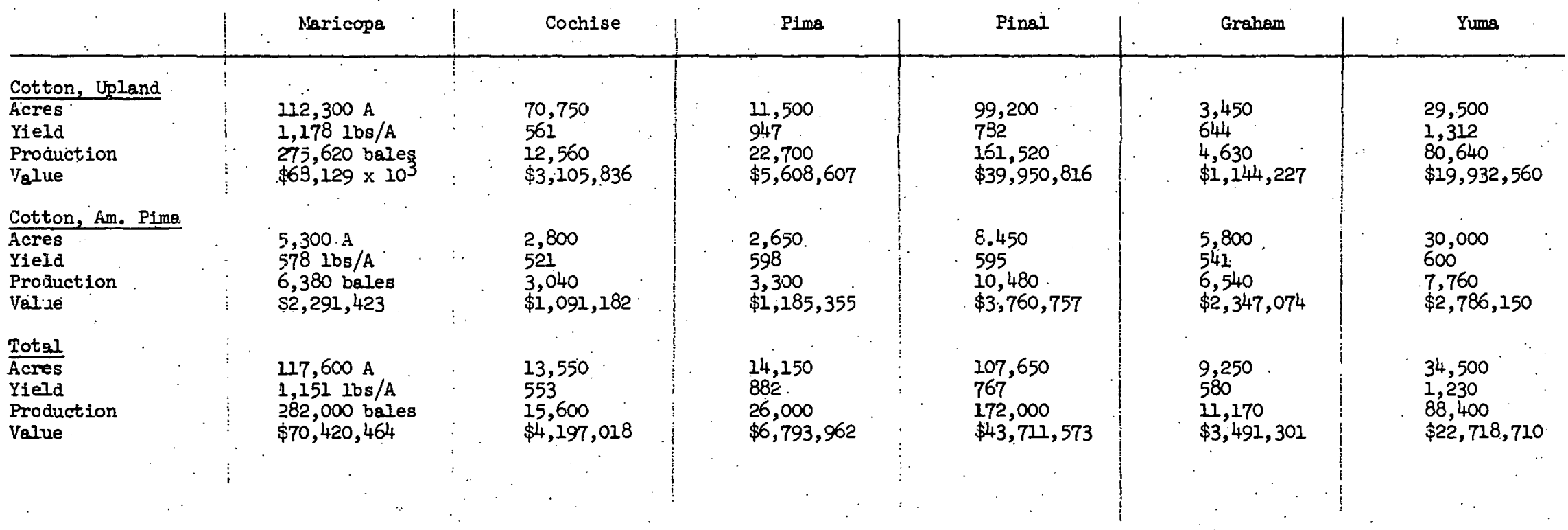


Tarle 6a (cont.)

Crop Information for Barley and wheat

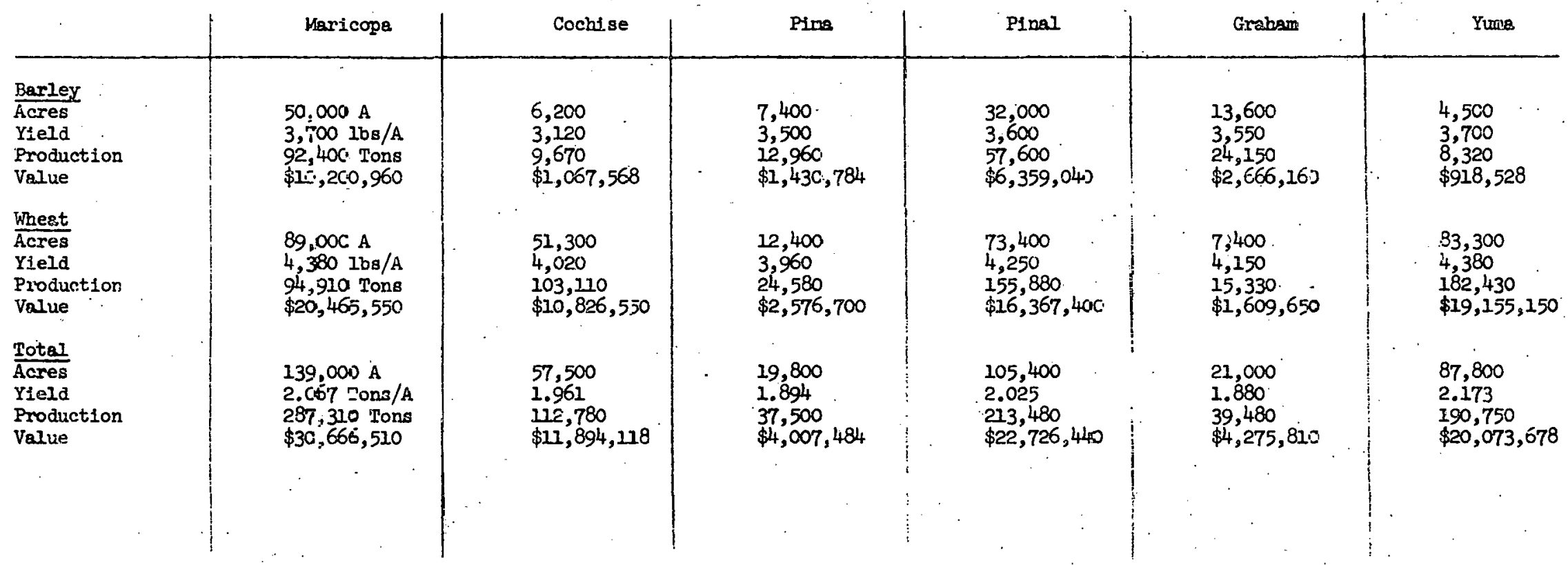


Table 6a (cont.)

Crop In-ormation for Oranges, Tangerines, Grepefruit, and Lemons

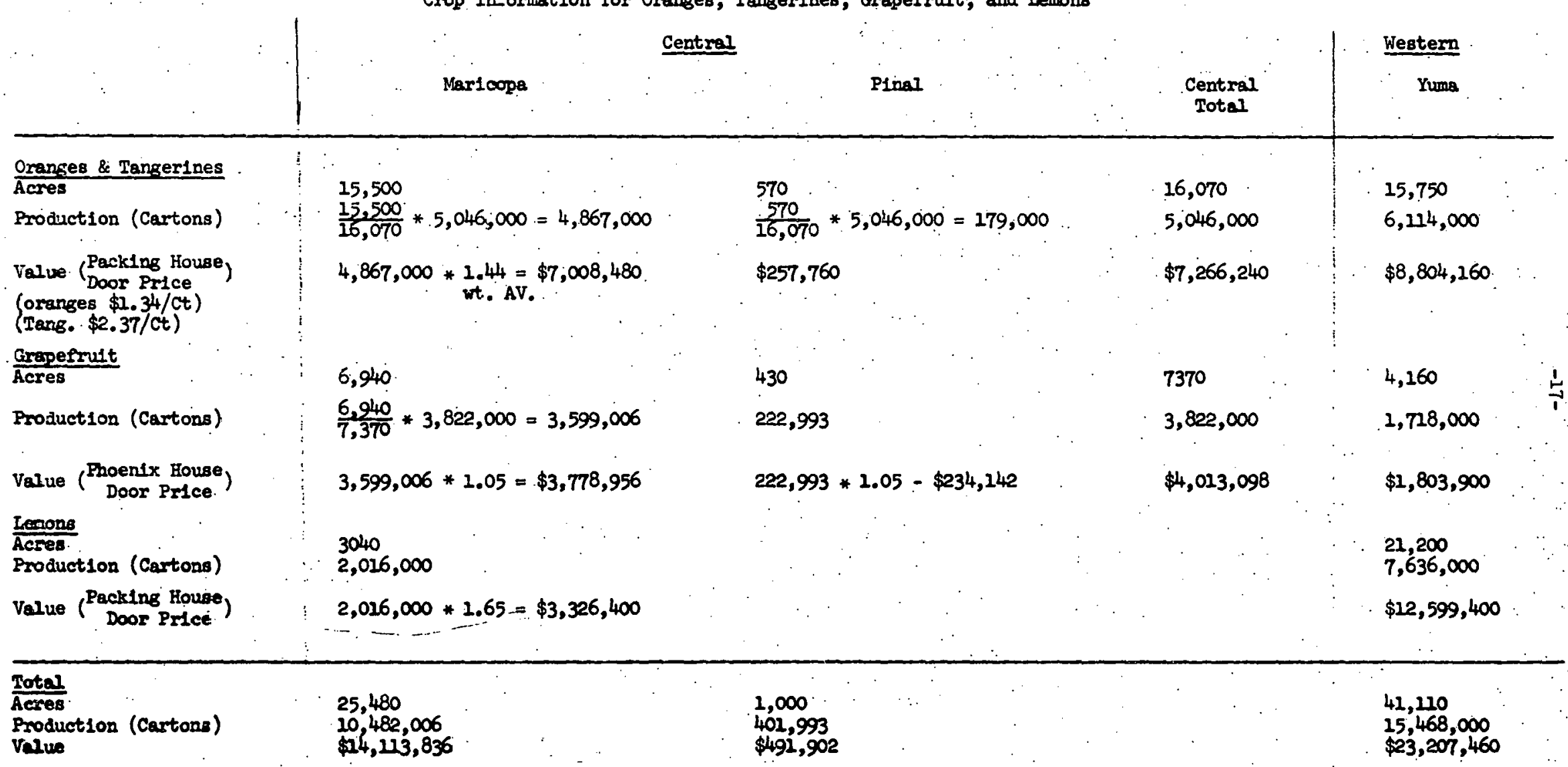


Tajle 6a (cont.)

Crop Irfo-mation for Vegetables

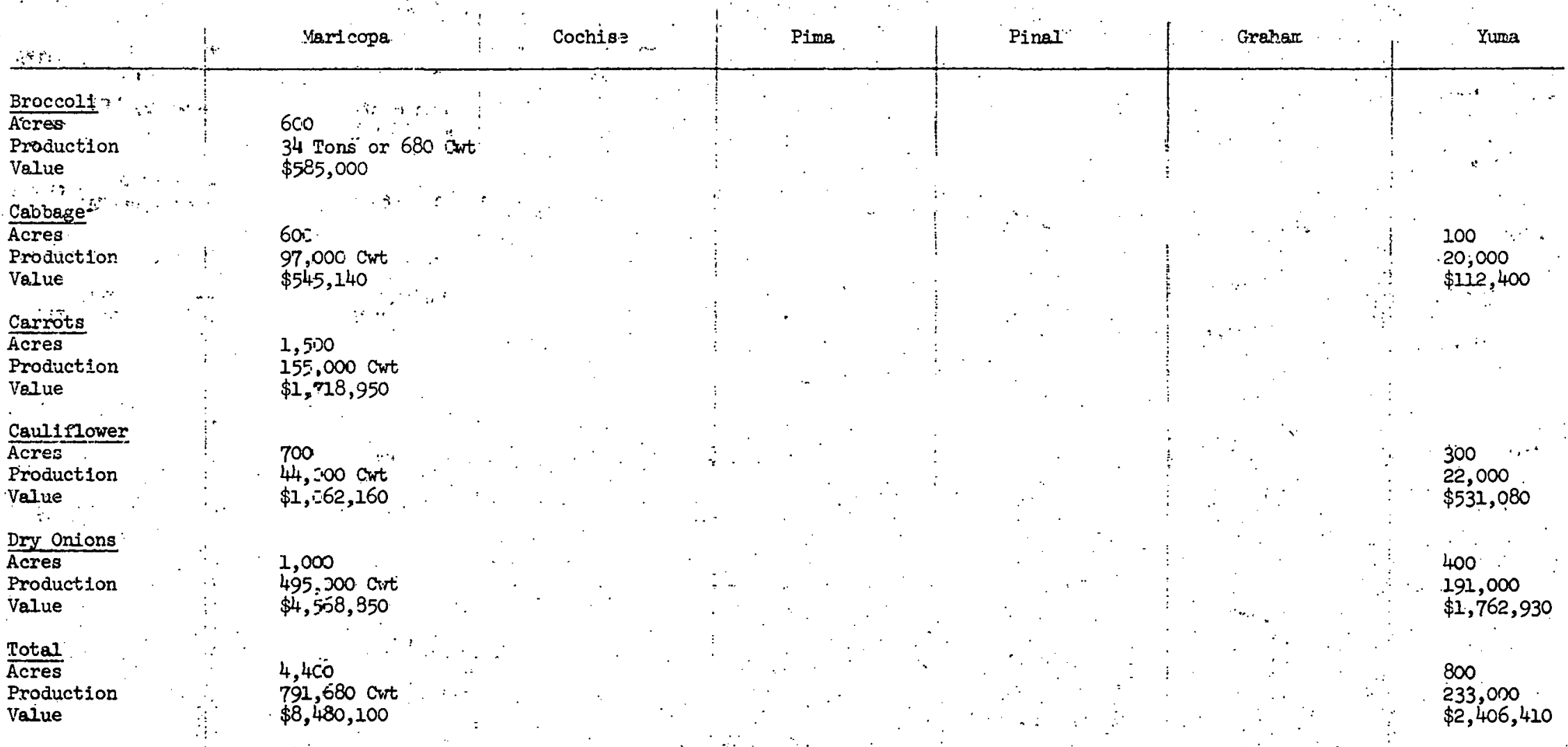


Table 7

Pump Information

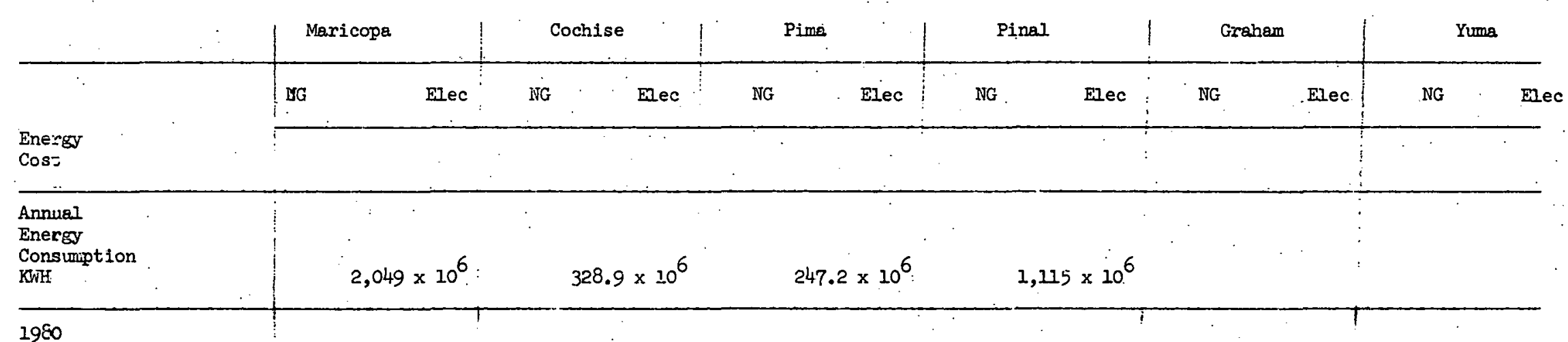

Availability 
Table 8

Other Data

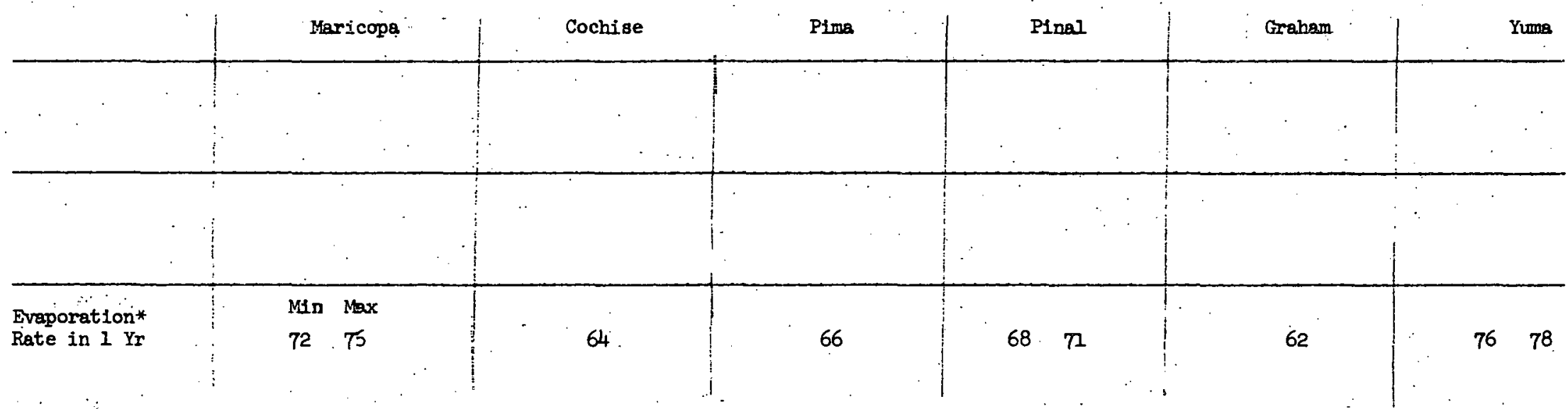

* Based on map, p. 12 of Ref [3]. 


\section{Appendix}

This appendix contains two additionel tables which may be of some interest. The information in the tables comes from [7]. Table AI is i list of the watex applied by crop. Table A2 gives energy information by crop. The crops are ordered by the amount of irrigation energy required. The notes on the bottom of the table are intended to clarify the numbers in the body of the table. 
Table Al

Total Water Applied by Crop

USDA and FED Report - 1974 Data. See Ref. [7]:

Cotton

Winter Wheat

Alfalfa

Grain Sorghum

Barley

Vegetables

Hay - other

Oranges

Sugar Beets

Lemons

Corn

Potatoes

Grapefruit

Corn Silage

Sorghum Silage

Seed Crops

Citrus - otliér

Grapes

Vegetables - Process
55.88 inches/acre-year 36.17

64.78

39.85

48.98

$31.8 \%$

31.97

63.85

56.38

63.71

47.60

48.41

64.44

47.77

48.00

63.20

62.18

48.92

62.4 
Table A2

Energy Information by Crop USDA \& FEA Report. Ref. [7] 1974 Data

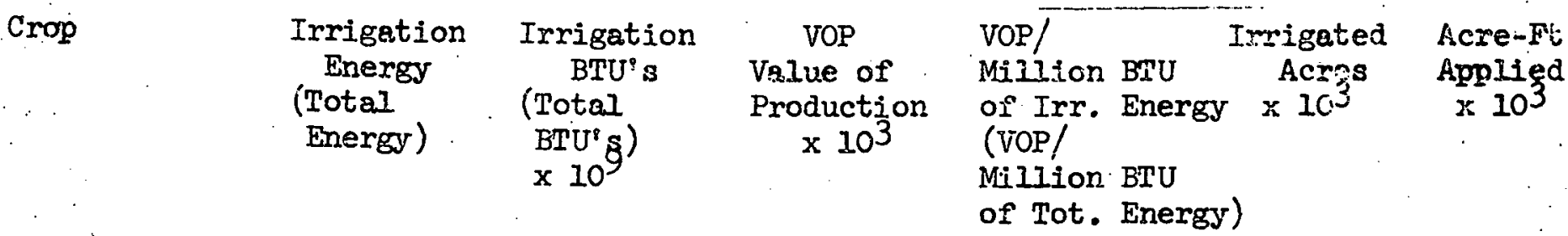

\begin{tabular}{|c|c|c|c|c|c|c|}
\hline Cotton & $\begin{array}{l}34.90 \%(i) \\
(36.6 \%)\end{array}$ & $\begin{array}{c}7764^{(1 i)} \\
(12548)\end{array}$ & $\$ 251,000$ & $\begin{array}{l}32.33^{(i i i)} \\
(20.0)\end{array}$ & 282.5 & 1315.6 \\
\hline Alfe.Ifo & $\begin{array}{c}20.37 \\
(14.76)\end{array}$ & $\begin{array}{l}4533 \\
(5063)\end{array}$ & 58,879 & $\begin{array}{c}15.20 \\
(13.60)\end{array}$ & 215 & 768.2 \\
\hline W. Wheat & $\begin{array}{l}13.26 \\
(13.80)\end{array}$ & $\begin{array}{l}2951 \\
(4734)\end{array}$ & 48,300 & $\begin{array}{l}16.54 \\
(10.31)\end{array}$ & 165.9 & 500.0 \\
\hline Grain Sorghum & $\begin{array}{l}11.95 \\
(11.01)\end{array}$ & $\begin{array}{l}2659 \\
(3778)\end{array}$ & 43,000 & $\begin{array}{l}16.17 \\
(11.38)\end{array}$ & 135.7 & 450.6 \\
\hline Barley & $\begin{array}{r}5.32 \\
\left(\begin{array}{l}4.96) \\
\end{array}\right. \\
\end{array}$ & $\left(\begin{array}{l}1183 \\
(1702)\end{array}\right.$ & 16,500 & $\begin{array}{r}13.95 \\
(19.69) \\
\end{array}$ & 49.1 & 200.4 \\
\hline $\begin{array}{c}\text { Vegetables } \\
.\end{array}$ & $\begin{array}{l}2.82 \\
(4.08) \\
\end{array}$ & $\begin{array}{r}628 \\
(1400) \\
\end{array}$ & 84,700 & $\begin{array}{l}134.87 \\
(60.50)\end{array}$ & 40.1 & 106.5 \\
\hline Orenges & $\begin{array}{r}2.29 \\
(4.09) \\
\end{array}$ & $\begin{array}{r}509 \\
(1402) \\
\end{array}$ & 10,026 & $\begin{array}{r}19.70 \\
(7.12) \\
\end{array}$ & 16.2 & 86.2 \\
\hline Hay other & $\begin{array}{r}1.68 \\
(1.19) \\
\end{array}$ & $\begin{array}{l}374 \\
(\quad 409) \\
\end{array}$ & 3,506 & $\begin{array}{l}9.37 \\
8.57)\end{array}$ & 23.8 & 63.4 \\
\hline $\begin{array}{c}\text { Lemons } \\
\vdots\end{array}$ & $\begin{array}{r}.96 \\
(1.73) \\
\end{array}$ & $\begin{array}{r}213 \\
(\quad 593) \\
\end{array}$ & 18,067 & $\begin{array}{c}84.82 \\
(30.47)\end{array}$ & 6.8 & 36.1 \\
\hline Sugar Beets & $\left(\begin{array}{l}.91 \\
.80) \\
\end{array}\right.$ & $\begin{array}{l}202 \\
274)\end{array}$ & 11,881 & $\begin{array}{r}58.82 \\
(43.36) \\
\end{array}$ & 7.3 & 34.3 \\
\hline $\begin{array}{c}\text { Grepefruit } \\
\end{array}$ & $\begin{array}{c}.77 \\
(1.42)\end{array}$ & $\left.\begin{array}{l}171 \\
487\end{array}\right)$ & 4,182 & $\begin{array}{c}24.46 \\
(8.59)\end{array}$ & 5.4 & 29.0 \\
\hline Corn. & $\begin{array}{r}.63 \\
(\quad .62) \\
\end{array}$ & $\begin{array}{l}140 \\
(213)\end{array}$ & 1,200 & $\begin{array}{l}8.57 \\
5.63)\end{array}$ & 6.0 & 23.8 \\
\hline Potatoas. & $\begin{array}{r}.63 \\
(.96) \\
\end{array}$ & $\begin{array}{l}140 \\
(\quad 331) \\
\end{array}$ & $1,1,739$ & $\begin{array}{r}83.85 \\
(35.47) \\
\end{array}$ & 5.9 & 23.8 \\
\hline
\end{tabular}

Notes: (i) Of the total irrigation energy used in Arizone, 34.90\% was used for cotton irrigation. of the total agriculture energy used in Arizona, $36.6 \%$ was used for cottor

(ii) BTU's used for irrigating cotton was $7764 \times 10^{9}$. BTU's used for growing cotton
was $12,548 \times 19^{9}$.

(iii) VOP per million BTU's of irrigation energy was \$32.33. VOP per million BIU's of agriculture energy was $\$ 20.00$. 


\section{References}

(1) Erie, I. J., French, O. F., Harris, K., "Consumptive Use of Water by Crops in Arizona," Technical Bulletin 169, Agriculturo Expt. Station, College of Agriculture, University of Arizona, Tuscon.

(2) Hathorn, S。 and Willett, G. S., "Arizona Pump Water Budgets, 1975 , Maracope County," Dept. of Agricultural Economics, College of Agriculture, University of Arizona, Tuscun, Arizona, October 1975.

(3) Hathorn, S. and Willett, G. S., "Arizona Pump Water Budgets, 1976, Cochise County;" Dept. of Agricultural Economics, College of Agriculture, University of Arizona, Tuscon, Arizone, October 1976.

(4) Hathorn, S. and Willett, G. S., "Arizona Pump Water Budgets, 1976, Pinal County," Dept. of Agricultural Economics, College of Agriculture, University of Arizona, Tuscon, Arizona, October 1976.

(5) Iallum, s. and Willett, G. S., "Arizona Pump Water Budgets, 1976, Pima County," Dept. of Agricultural. Economics, Cullege of Agriculture; University of Arizona, Tuscon, Arizona, October 1976.

(6) "1975 Arizona Agriculture Statistics" Compiled by Arizona Cropland Liveatock Report1ng Service, Phoenix, Arizona, Bulletiu S-11, Mar. 1976."

(7) "Energy and U.S. Agriculture: 1974 Data Bese,". Federal Energy Administration, U.S. Dept. of Agriculture. Office of Energy Conservation and Environment, Economic Research Service, Sept. 1976, FEA/D-76/459.

(8) "Phase I, Arizona State Water Pla.n, Inventory of Resources and Uses," Arizona Water Commission, July 1975.

(9) Dutt, G. R. and McCreory, T. W., "The Quality of Arizone's Domestic, Agricultural, and Industrial Waters," Agriculture Experiment Station, University of Arizona, Report No. 256, Feb. 1970. 
Distribution:

DOE/DSE J. Wiesiger

1223 R. R. Prairie

1223 I. J. Hall (3)

$3141 \quad$ (5)

3151 (3) for DOE/TIC

3172-3 (25) for DOE/TIC

5719 D. G. Schuler

5740 V. L. Dugan

57.42 L. Lukens

$5743^{\circ}$ S. G. Vandevender

(3)

8266 (1) 